\title{
Diet of the American mink Mustela vison and its potential impact on the native fauna of Navarino Island, Cape Horn Biosphere Reserve, Chile
}

\author{
Dieta del visón norteamericano Mustela vison y su impacto potencial sobre la fauna nativa \\ de Isla Navarino, Reserva de Biosfera Cabo de Hornos, Chile
}

ELKE SCHÜTTLER ${ }^{1,2,3, *}$, JAIME CÁRCAMO ${ }^{4}$ \& RICARDO ROZZI ${ }^{2,5}$

\author{
${ }^{1}$ Department of Conservation Biology, Helmholtz Centre for Environmental Research-UFZ, \\ Permoserstrasse 15, 04318 Leipzig, Germany \\ ${ }^{2}$ Omora Ethnobotanical Park (Institute of Ecology and Biodiversity-IEB, Universidad de Magallanes, and Omora \\ Foundation), Puerto Williams, Antarctic Province, Chile \\ ${ }^{3}$ Lehrstuhl für Landschaftsökologie, Technische Universität München-Weihenstephan, Am Hochanger 6, 85350 Freising, \\ Germany \\ ${ }^{4}$ Instituto de la Patagonia, Universidad de Magallanes, Avenida Bulnes 01890, Punta Arenas, Chile \\ ${ }^{5}$ Department of Philosophy, University of North Texas, Denton, TX 76201, USA \\ *e-mail for correspondence: elke.schuettler@ufz.de
}

\begin{abstract}
Invasive exotic species of mammalian predators represent a major cause of vertebrate animal extinctions on islands, particularly those that lack native mammalian carnivores. In 2001, the American mink (Mustela vison) was recorded for the first time on Navarino Island, in the Cape Horn Biosphere Reserve $\left(55^{\circ} \mathrm{S}\right)$ in Chile, representing the southernmost population of mink worldwide. In order to assess its potential impact on native fauna, we studied its diet on Navarino Island, as part of an integrative management program on invasive species. Over a three-year period (2005-2007) we collected 512 scats in semi-aquatic habitats: marine coasts, riparian and lake shores. Overall, the main prey was mammals (37\% biomass), and birds (36 $\%$ ), followed by fish (24\%). Over the spring and summer, mink consumed significantly more birds, whereas mammals constituted the main prey over the autumn and winter when migratory birds had left the area. Among birds, the mink preyed mainly on adult Passeriformes, followed by Anseriformes and Pelecaniformes, caught as chicks. Among mammals, the exotic muskrat (Ondatra zibethicus) was the most important prey, and together with the native rodent Abrothrix xanthorhinus it accounted for $78 \%$ of the biomass intake. For an integrated management of invasive exotic mammal species on Navarino Island and in the Cape Horn Biosphere Reserve it is important to further research interactions established here among the various introduced mammals, and to initiate immediate control of the mink population in its initial stage of invasion.
\end{abstract}

Key words: conservation, exotic mammals, management, mustelids, waterbirds.

\section{RESUMEN}

Las especies exóticas de mamíferos carnívoros invasores constituyen una de las principales causas de extinciones de vertebrados en islas, particularmente en aquellas que carecen de predadores mamíferos nativos. En 2001, el visón norteamericano (Mustela vison) fue registrado por primera vez en Isla Navarino en la Reserva de Biosfera Cabo de Hornos $\left(55^{\circ} \mathrm{S}\right)$ en Chile, representando la población de visones más austral del mundo. Para estudiar su impacto potencial sobre la fauna nativa, estimamos su dieta en Isla Navarino como parte de un programa de control de especies invasoras. Durante tres años (2005-2007) colectamos 512 fecas en diversos hábitats semiacuáticos: costa marina, riberas de ríos y lagos. La dieta consistió principalmente en mamíferos (37 $\%$ biomasa), aves (36 \%) y peces (24 \%). Durante la primavera y el verano el visón consumió significativamente más aves, sin embargo los mamíferos constituyeron la presa principal durante el otoño y el invierno, cuando las aves migratorias han abandonado la región. La depredación sobre aves afectó principalmente a Passeriformes adultos, seguidos por Anseriformes y Pelecaniformes que fueron capturados como polluelos. Respecto a los mamíferos, un roedor exótico, la rata almizclera (Ondatra zibethicus), fue la presa principal y junto al roedor nativo Abrothrix xanthorhinus constituyó el $78 \%$ de la biomasa de presas de mamíferos. Para un manejo integral de especies de mamíferos exóticos invasores en Isla Navarino y la Reserva de Biosfera Cabo de Hornos es importante desarrollar investigación sobre las interacciones entre los mamíferos introducidos e iniciar un control inmediato de la población de visones en su estado inicial de invasión.

Palabras clave: conservación, mamíferos exóticos, manejo, mustélidos, aves acuáticas. 


\section{INTRODUCTION}

Invasive exotic species and their impacts are currently regarded as one of the major causes of anthropogenic global change (Sala et al. 2000) and biodiversity loss (Vitousek et al. 1997). In particular, invasive predators can have severe impacts on native prey populations, especially on remote islands due to prey naivety or a lack of their natural predators or competitors that would have otherwise limited their success (Elton 1958, Macdonald \& Thom 2001). In the case of evolutionary isolation of native species, introductions of carnivore species to island ecosystems can even lead to local extinctions, as it has been documented for several bird species (Courchamp et al. 2003).

The American mink (Mustela vison Schreber, 1777) is a successful alien predator in most European countries, where it has established feral populations following its introduction from North America for the purpose of fur farming (reviews in Macdonald \& Harrington 2003, Bonesi \& Palazon 2007). In South America the mink was introduced to Chile and Argentina in the 1930s (Jaksic et al. 2002), where populations established in southern Chile (Sandoval 1994, Rozzi \& Sherriffs 2003, Anderson et al. 2006a) and Argentina (Pagnoni et al. 1986). Mink are medium-sized mustelids with a body weight of about $1 \mathrm{~kg}$. They are semi-aquatic mammals found associated with marine shore habitats, river banks, lake shores, freshwater and saltwater marshes. As generalist predators their diet includes prey from both aquatic and terrestrial sources in variable proportions and strongly reflects local and seasonal availability of prey (Dunstone 1993).

Being a highly adaptable and opportunistic predator various studies in Europe have shown that mink can be detrimental to native species (Macdonald \& Harrington 2003). The most apparent impact of the mink is a reduction in the range or population size of native prey as has been well documented for seabird colonies on islands (Clode \& Macdonald 2002, Nordström et al. 2004), ground-nesting inland water birds (Ferreras \& Macdonald 1999), intertidal marine communities (Delibes et al. 2004), rodents (Jefferies 2003) and amphibians (Ahola et al. 2006). Negative impacts due to competition are subject to discussion for the
European mink (Maran et al. 1998, Sidorovich et al. 2001). In South America mink have caused reductions in waterbird populations (Lizzaralde \& Escobar 2000). They are also considered to be responsible for the decline of the river otter Lontra provocax (Thomas, 1908) (Previtali et al. 1998), although Medina (1997) found little support on competition for space and food.

The case of Navarino Island represents a recent invasion of the mink, where it was first recorded in 2001 (Rozzi \& Sherriffs 2003). Navarino Island is located south of Tierra del Fuego, from which it is separated by the Beagle Channel. At numerous points this channel is less than $5 \mathrm{~km}$ wide. Mink that escaped or were released from mink farms on Tierra del Fuego might have swum across the Beagle Channel, reaching Navarino Island, and other islands of the Cape Horn Biosphere Reserve (Rozzi \& Sherriffs 2003). Here, they represent a new guild because Navarino Island lacks native terrestrial mammalian predators. Thus among the mechanisms by which introduced carnivores affect the local biota (competition, disease, interbreeding, predation, Macdonald \& Thom 2001) predation is the most expected mechanism for mink on Navarino, with possible indirect effects on trophic webs.

On Navarino Island the most diverse and abundant group of vertebrates are birds (Rozzi et al. 2006a). Many of them are ground-nesting, and expected to be especially vulnerable to predation from introduced mink as behavioral adaptations to terrestrial predators might lack (Anderson et al. 2006a, Soto \& Cabello 2007). Although the Cape Horn region is part of one of the most pristine areas in the world (Mittermeier et al. 2003), this archipelago has not only been invaded by mink, but also by feral domestic animals, rodents and two more North American wild fur mammals: the beaver (Castor Canadensis Kuhl, 1820) and the muskrat (Ondatra zibethicus Linnaeus, 1766). In total, the assemblage of exotic terrestrial mammals on the island outnumbers their native counterparts (Anderson et al. 2006a). Some of these exotic species of rodents might represent prey for the mink, thereby generating possible predator-prey interactions among exotic species.

The prime purpose of this study is to quantify the composition of the diet of the 
southernmost population of American mink in its initial stage of colonization, considering seasonal and habitat variations, in order to provide an initial baseline diagnosis about its potential impact on native and exotic fauna of Navarino Island, and the Cape Horn Biosphere Reserve. Our hypotheses are as follows: First, given that birds are the most abundant group of terrestrial vertebrates on Navarino, birds could represent the main prey group in the diet of the mink. Second, given that in Cape Horn several bird species and/or populations are winter migrants, we expect birds to be the main prey especially during the breeding season and in marine coastal habitats where bird populations are particularly abundant and diverse. Third, given that the exotic muskrat is an important prey for mink in its original distribution range; this rodent species could also constitute an important prey for mink populations in the area of Cape Horn, thus facilitating the arrival of the newcomer mink (i.e., invasional meltdown hypothesis by Simberloff \& Von Holle 1999). We will try to estimate the absolute number of birds, mammals, and fish that mink remove monthly and discuss these results in the context of conservation and management with a special focus on the potential impact that the recently introduced mink might have on native bird, especially ground-nesting, and mammal populations.

\section{MATERIAL AND METHODS}

\section{Study area}

The study was carried out on Navarino Island $\left(2528 \mathrm{~km}^{2}\right)$, located at the extreme southern tip of South America (Fig. 1). The island forms part of the Cape Horn Biosphere Reserve $\left(54^{\circ}\right.$. $56^{\circ} \mathrm{S}$ ) and belongs to the Magellanic SubAntarctic Evergreen Rainforest ecoregion, recently identified as one of the 24 most pristine wilderness areas of the world (Mittermeier et al. 2003). The main habitats include (i) evergreen and deciduous forests dominated by the genus Nothofagus, (ii) peatlands, moorlands, and bogs, (iii) alpine communities dominated by cushion plants and lichens, (iv) streams and lakes, and (v) thickets or scrublands in naturally or anthropogenically disturbed areas (Pisano 1977, Rozzi et al. 2006b). The climate is oceanic, with a low annual thermic fluctuation $\left(<5{ }^{\circ} \mathrm{C}\right)$, a mean annual temperature of $6{ }^{\circ} \mathrm{C}$, and an annual precipitation of $467.3 \mathrm{~mm}$ (Pisano 1977). During the winter, streams and lakes are icebound. The human population is concentrated in the town of Puerto Williams, the capital city of the Chilean Antarctic Province, on the northern coast of Navarino. Access to the town, rural settlements and navy stations relies mostly on access from the sea, except for a dirt road that connects the entire northern coast of Navarino Island.

\section{Potential vertebrate prey on Navarino Island}

With 154 species, birds represent the most abundant and diverse group of terrestrial vertebrates on the island (Couve \& Vidal 2003, Rozzi et al. 2006a). Native mammals include only five species: one Artiodactyla, two Chiroptera, and two Rodentia. At present, exotic mammals include eleven species, therefore outnumbering native species. They include four species of rodents: Castor canadensis, Mus musculus (Linnaeus, 1758), Ondatra zibethicus, and Rattus norvegicus (Berkenhout, 1769) (Anderson et al. 2006a). Ondatra zibethicus is an important native prey to mink in North America (Dunstone 1993). As far as freshwater fish are concerned, Navarino Island only hosts one common native species (Galaxias maculatus Jenyns, 1842), two extremely rare native species (Applochiton spp.) and two exotic species of trout, Salvelinus fontinalis (Mitchill, 1814), and Oncorhynchus mykiss (Walbaum, 1792) (Moorman 2007). However, the marine fish fauna in the Beagle Channel is rich and includes more than 50 species (López et al. 1996). There are no amphibians or reptiles present on Navarino Island (Anderson et al. 2006a).

\section{Dietary analysis}

Diet was analyzed by examining 512 feces (= scats) collected from 36 sites on Navarino Island between April 2005 and March 2007. The sites included different semi-aquatic habitats: 13 marine coastal sites, 14 sites along lake shores, and nine sites along riparian shores. The majority of the sites ( 28 sites) were 
located at the northern margin of Navarino Island due to the limited accessibility of the southern areas. To ensure that collected scats represented different individuals we sampled sites that were separated by at least three $\mathrm{km}$ (the average linear territory size described for the American mink, Dunstone 1993). We searched for scats at all sites over the summer. Due to climatic conditions and accessibility, we only conducted scat searches over the spring, autumn, and winter seasons at coastal sites. All scats were frozen for long-term storage.

Collected scats were thawn and soaked in water overnight prior to sieving $(0.3 \mathrm{~mm})$. The washed scats were then dried at $50{ }^{\circ} \mathrm{C}(24 \mathrm{~h})$ and stored in paper bags. We sorted the undigested prey remains into six categories (mammals, birds, fish, insects, crustaceans, mollusks) using a binocular microscope. Seeds and plant material were excluded from the analysis as we suspected that this was a result of secondary prey, accidental intake or adhesion after defecation. We estimated the percentage volume of each prey category per scat to the nearest $10 \%$ and weighed it to $0.01 \mathrm{~g}$.
For the identification of mammals and birds we used the reference collections of the Instituto de la Patagonia, Universidad de Magallanes, complemented by our own additional collections, and local keys (Reise 1973, Chehébar \& Martín 1989, Reyes 1992, Rau \& Martínez 2004). Mammals were identified to the species level by examining hair samples; birds were identified to the order level, the taxonomic level a microscopic examination of feathers permits (Day 1966). To address the question of which age category birds are preferably consumed by mink we classified birds that had been identified taxonomically into adults and chicks. We assigned the sample to chicks if at least three of the following features applied: long slender barbs at short rhachis, presence of papillae, truncated feather shape, lack of coloration, lack of pennaceous barbs, and a small amount of bones in the sample (Ewart 1921, Busching 2005). Insects were identified by a local entomologist to the species level, and where this was impossible to the next higher taxonomic level (order, subclass).

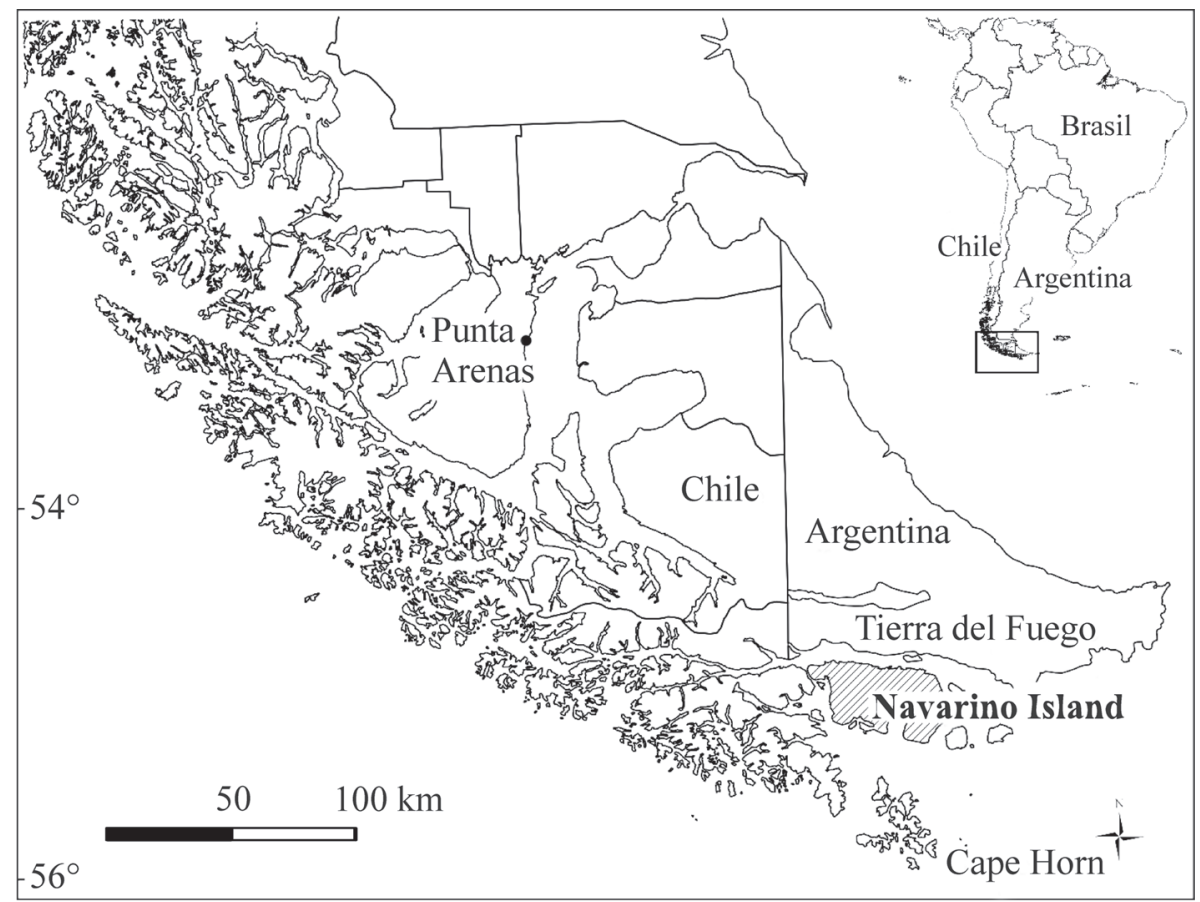

Fig. 1: Map of southern South America with the study area Navarino Island south of the Argentinean portion of Tierra del Fuego (separated by the Beagle Channel).

Mapa del sur de Sudamérica con el área de estudio Isla Navarino al sur de Tierra del Fuego Argentina (separado por el canal Beagle). 
To quantify the relative contribution of prey groups to mink's diet we applied three indices; the first two are commonly used (Jedrzejewska \& Jedrzejewski 1998):

(1) Percentage of relative frequency of occurrence of each food item (RFO), calculated as the number of occurrences of a prey category divided by the number of occurrences of all prey categories. With this index, small prey items tend to be overrated in terms of importance.

(2) Percentage biomass of a given prey item (BIO) estimated by multiplying its dry mass by its empirically determined coefficients of digestibility. This coefficient is measured as the ratio of fresh mass of a given prey to the dry mass of its remains in scats (Jedrzejewska et al. 2001). We applied the following correction factors: mammals (17.3), birds (17.2), eggs (687.5), fish (30.8), crustaceans and mollusks (14.8), provided by Brzezinski \& Marzec (2003). For insects we used the value (5.0) provided by Lockie (1961). Calculating the biomass reflects the real intake of prey as it takes into account different sizes and digestibility of prey (Brzezinski \& Marzec 2003).

(3) Percentage occurrence of the dominant item (POD) with the item constituting the largest volume class considered as the dominant one (Hammershøj et al. 2004). This method can compensate for the disadvantage of secondary prey intake.

\section{Statistics}

We conducted Spearman's rank correlations between the corresponding prey groups of different indices (RFO, BIO, POD) in order to evaluate whether those indices were comparable with each other. We assessed differences in the diet composition between habitats and seasons using chi-squared tests with Yates' continuity and Bonferroni corrections, Fisher's exact tests when expected values were less than five, and two-sample tests for equality of proportions, all two-sided, running the $\mathrm{R}$ version 2.7.1. ( $\mathrm{R}$ Development Core Team 2008).

In order to measure the degree of specialization of mink in different habitats and seasons we calculated its food-niche breadth for the six defined food categories using Hurlbert's standardization of Levins' $B$ index (Levins 1968, Hurlbert 1978, Krebs 1999):

$B_{s}=\frac{(B-1)}{(n-1)}$

with $B_{s}=$ standardized niche breadth, $B=$ Levins' index, $n=$ number of food categories,

$B=\frac{1}{\sum p_{i}^{2}}$

where $p_{i}$ is the proportion of items in the diet that are of food category $i$. The proportion was calculated for each of the three indices used in this study (RFO, BIO, POD). The range of Levins' $B$ index is 1 to $n$. Therefore it depends on the number of food categories. The standardized niche breadth $B_{s}$ is independent of $n$ and has a range from 0 to 1 , with 1 indicating the broadest niche.

We estimated the intake of prey groups by the mink in order to evaluate its impact on prey populations where abundances are known. To assess how many birds, mammals, and fish a single mink might consume during a warm month, we followed the approach developed by Jedrzejewska \& Jedrzejewski (1998) in Bartoszewicz \& Zalewski (2003). Accordingly, the number of a given prey group eaten per day per mink $\left(N_{p d}\right)$ was calculated as:

$N_{p d}=\frac{D F C \times B_{p}}{W t_{p}}$

where $D F C$ is the average daily food consumption of mink (app. $190 \mathrm{~g}, 153 \pm 48 \mathrm{~g}$ for females, $231 \pm 72 \mathrm{~g}$ for males, estimated from Dunstone 1993), $B_{p}$ is the fraction of given prey biomass in the mink diet, and $W t_{p}$ is the wet mass of a given prey: $75 \mathrm{~g}$ for small birds, $35 \mathrm{~g}$ for small rodents, $1100 \mathrm{~g}$ for the muskrat, and $113 \mathrm{~g}$ for fish (Dunstone 1993, Bartoszewicz \& Zalewski 2003). We used an overall index of $75 \mathrm{~g}$ for birds as our results indicated that bigger birds (e.g., Anseriformes) were almost exclusively consumed as chicks.

\section{RESULTS}

The analysis of scat content showed that the mink diet consisted mainly of mammals and birds (Fig. 2). Combined, both taxonomic groups accounted for more than half of the 
mink diet using the relative frequency of occurrences index (59.3\% RFO), for $68.0 \%$ when estimated by the biomass index (BIO), and for $80.1 \%$ with the dominant item method (POD). In the overall diet, mammals were more important than birds using RFO $\left(\chi^{2}=7.79, \mathrm{df}=\right.$ $1, \mathrm{P}=0.005)$, but not significantly different form birds in biomass intake $\left(\chi^{2}=0.73, \mathrm{P}=\right.$ $0.394)$. Fish were the third most important component in the mink diet accounting for 14.1-23.7 \% . Overall, we found that terrestrial food (72.5-83.2\% mammals, birds, insects) provided a much more important source of food for mink than did aquatic prey (16.8-27.5\% fish, crustaceans, mollusks) (for all indices $\chi^{2}$ values $\geq 375.35$, all $\mathrm{df}=1$, all $\mathrm{P}$-values $<$ $0.0001)$.

\section{Variations in mink diet among habitats}

All three indices correlated significantly with each other (Spearman rank correlations, all $\mathrm{n}=$ 6 prey groups: $\mathrm{RFO}$ with $\mathrm{BIO}, \mathrm{r}_{\mathrm{s}}=0.94, \mathrm{P}=$ 0.017; RFO with POD, $\mathrm{r}_{\mathrm{s}}=1.0, \mathrm{P}=0.003$; $\mathrm{BIO}$ with $\left.\mathrm{POD}, \mathrm{r}_{\mathrm{s}}=0.94, \mathrm{P}=0.017\right)$. For this reason, we focused on the most conservative index, the dominant item method (POD), to evaluate differences in prey composition between scats collected in different habitat types. Mink diet in the summer varied significantly among different habitat types (Fig. 3 ). The dominant item index differed between riparian and marine coastal habitats (Fisher's exact test, $\mathrm{df}=5, \mathrm{P}<0.0001)$, and riparian and lake habitats $(\mathrm{df}=5, \mathrm{P}<0.0001)$. Differences between marine coastline and lakes were also significant $(\mathrm{df}=5, \mathrm{P}=0.031)$, but the contrast in values was less pronounced. In lake habitats, the proportion of birds $(58.0 \%)$ exceeded the proportion of mammals $(34.1 \%)$ significantly $\left(\chi^{2}=9.15, \mathrm{df}=1, \mathrm{P}=0.002\right)$. In contrast, in riparian habitats bird prey was much less frequent than mammal ones (22.4 versus 55.1 $\left.\%, \chi^{2}=9.67, \mathrm{P}=0.002\right)$. Indeed, in riparian habitats the consumption of birds by the mink was significantly lower than in marine $\left(\chi^{2}=\right.$ $6.62, \mathrm{P}=0.01)$ and lake habitats $\left(\chi^{2}=10.67, \mathrm{P}\right.$ $=0.001)$. Regarding the other taxonomic groups, fish was only found to be frequent prey in marine coastal habitats $(17.4 \%)$. Thus the consumption of fish by the mink was significantly higher in marine habitats

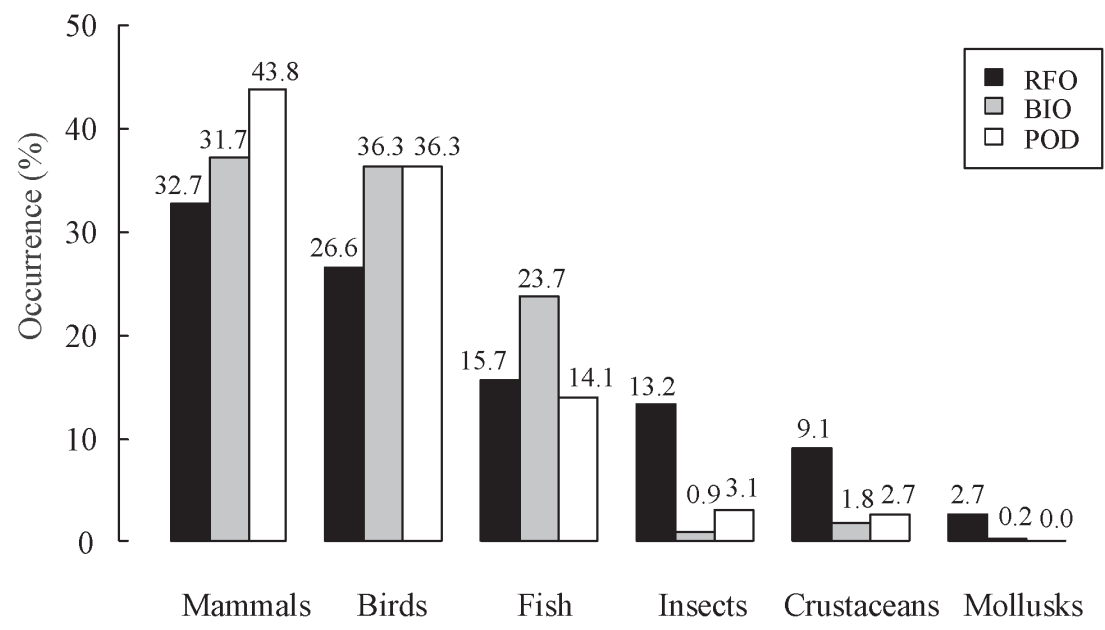

Fig. 2: Overall occurrence of prey categories in scats of American mink on Navarino Island. Percentages are based on data from all scats $(n=512)$ collected from three types of semi-aquatic habitats (marine, riparian, lake) over the four seasons during a three-year period (2005-2007); RFO $=$ relative frequency of occurrences of each prey category, $\mathrm{BIO}=$ percentage of biomass consumed, $\mathrm{POD}=$ percentage of occurrence of each prey category as the dominant item

Presencia total de categorías de presa en heces del visón en Isla Navarino. Los porcentajes están basados en datos de todas las heces $(n=512)$ recolectadas en tres diferentes tipos de hábitats semiacuáticos (costa marina, riberas de ríos y lagos) en las cuatro estaciones durante un período de tres años (2005-2007); RFO = frecuencia relativa de presencia de cada categoría de presa, $\mathrm{BIO}=$ porcentaje de biomasa consumida, $\mathrm{POD}=$ porcentaje de presencia de cada categoría de presa como ítem dominante. 
compared to lake $\left(\chi^{2}=5.78, \mathrm{P}=0.016\right)$, and riparian habitats $\left(\chi^{2}=6.19, \mathrm{P}=0.013\right)$. Regarding other prey (insects, crustaceans, mollusks), insects were found to be the dominant item in riparian habitats occurring in $20.4 \%$ of the analyzed scats, while crustaceans were the most important prey in marine coastal habitat accounting for $5.2 \%$.

\section{Variations in mink diet among seasons}

We assessed seasonal differences in the diet of the mink in marine coastal habitats focusing on the POD index as done for differences between habitats. Diet composition between springsummer and autumn-winter, respectively, was insignificant (Fisher's exact test, $\mathrm{df}=5, \mathrm{P}=$

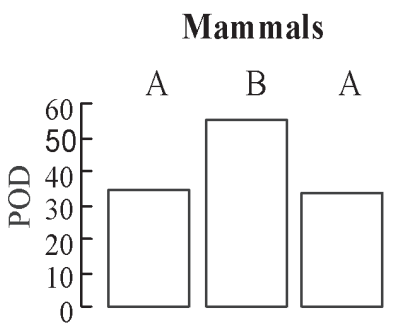

Marine Rivers Lakes

Fish

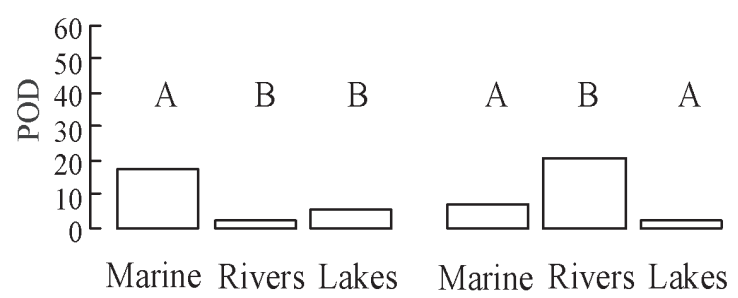

Fig. 3: Differences in the consumption of mammals, birds, fish, and other prey (insects, crustaceans, mollusks) by mink over the summer in different habitat types $(\mathrm{n}=292$ scats). For each graph different letters above the bars indicate significant differences $(\mathrm{P}<0.05$ with 2 -sample tests for equality of proportions) in the percentage of occurrence of the dominant item (POD) in a prey group among habitat types.

Diferencias en el consumo de mamíferos, aves, peces y otra presa (insectos, crustáceos, moluscos) por el visón durante el verano en diferentes tipos de hábitats $(n=292$ heces). Hábitats con distintas letras indican diferencias significantes (prueba de igualdad de proporciones, $\mathrm{P}<$ $0,05)$ en el porcentaje de presencia del ítem dominante (POD) en una categoría de presa.
0.119 , and $\mathrm{P}=0.233$, respectively) so that data were pooled for the warm season (springsummer) and the cool season (autumn-winter). However, the diet of the mink in warm and cool seasons varied significantly $(\mathrm{df}=5, \mathrm{P}<$ 0.0001) (Fig. 4). Scats collected during the warm season at marine coastal sites were approximately equally dominated by mammals and birds (37.6 versus $40.7 \%, \chi^{2}=0.4, \mathrm{df}=1$, $\mathrm{P}=0.528)$. In contrast, during the cool season, scats collected in marine habitats were dominated by mammal items (59.8\% POD), while birds, which were dominant items in only $16.2 \%$ of analyzed scats, were significantly
Mammals

A

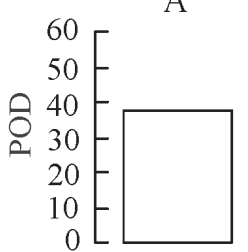

Warm
B

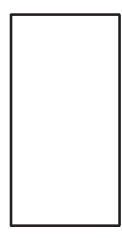

Cool
Birds
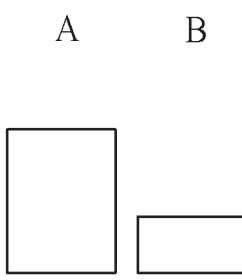

Warm Cool
Fish

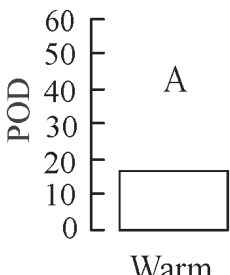

A

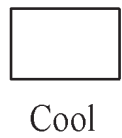

Other prey

A $\quad$ A

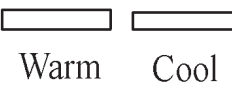

Fig. 4: Differences in the consumption of mammals, birds, fish, and other prey (insects, crustaceans, mollusks) by mink during warm (spring-summer) and cool (autumn-winter) seasons in marine coastal habitat $(n=375$ scats $)$. For each graph different letters above the bars indicate significant differences $(\mathrm{P}<0.05$ with 2 -sample tests for equality of proportions) in the percentage of occurrence of the dominant item (POD) in a prey group among seasons.

Diferencias en el consumo de mamíferos, aves, peces y otra presa (insectos, crustáceos, moluscos) por el visón durante la temporada cálida (primavera-verano) y la temporada fría (otoño-invierno) en hábitat marino $(n=292$ heces). Temporadas con distintas letras indican diferencias significantes (test de igualdad de proporciones, $\mathrm{P}<0,05$ ) en el porcentaje de presencia del ítem dominante (POD) en una categoría de presa. 
less consumed $\left(\chi^{2}=45.33, \mathrm{df}=1, \mathrm{P}<0.0001\right)$. Fish represented the dominant item in 16.7$19.7 \%$ of scats in warm and cool seasons, and no significant temporal variation could be determined. Furthermore, no significant seasonal fluctuations for the other prey groups could be found, which made up less than $5 \%$ of the dominant items in warm and cool seasons.

\section{Trophic niche breadth}

The standardized trophic niche breadths during the summer season were highest for mink inhabiting marine coastal habitats (Table 1). Lake habitats exhibited low values of trophic niche breadth. Mink diet in lake habitats concentrated on birds (58\% POD); fish and other prey groups were almost absent (Fig. 3). In marine habitats, mink diet showed the highest variation during summer, and the lowest during winter when mink relied essentially on mammals (63.6 \% POD), and entire prey groups (insects, crustaceans, mollusks) lacked in its diet. For spring and autumn the trophic niche breadths were intermediate.

\section{Taxonomic identification}

We identified prey groups from 193 scats collected during the warm season (springsummer) in marine coastal habitat. We focused on this sample as food niche breadth was broadest in marine habitats, and in order to coincide with the breeding season of birds. Birds were the most diverse group of prey on Navarino Island. Seven of the twelve orders of birds breeding on the island were present in the scats analyzed (Table 2). Passeriformes were the most abundant order in the diet, with indices from 10.2-14.8\% (RFO, BIO, POD). However, Pelecaniformes, Anseriformes, and eggs also played an important role in terms of biomass intake. Together these four groups accounted for $76.2 \%$ of the bird biomass consumed by mink. Passeriformes were mainly caught as adults, whereas all other bird orders were caught as chicks, with the difference being highly significant $\left(\chi^{2}=37.9, \mathrm{df}=1, \mathrm{P}<0.0001\right)$.

As far as mammals are concerned, the two dominant species were the native rodent Abrothrix xanthorhinus (Waterhouse, 1837) and the exotic muskrat (Ondatra zibethicus), with 8.9-14.8\%, and 8.7-15.2 \% (RFO, BIO, POD), respectively (Table 2). Together, $A$. xanthorhinus and $O$. zibethicus represented $78.2 \%$ of the mammal biomass consumed by the mink on Navarino Island. The relative importance of Oligoryzomys longicaudatus (Bennett, 1832), the second native rodent species on the island, was modest. Its relative frequency of occurrence, biomass and dominance as a prey item were less than a third of the values determined for A. xanthorhinus and $O$. zibethicus. The presence of the house mouse (Mus musculus) in the diet was negligible. It was found only in three samples collected in the vicinity of houses. Noticeably, the two other exotic rodent species, namely the beaver (Castor canadensis) and the Norway rat (Rattus norvegicus), were not found in any of the scats collected in marine coastal habitats over the spring and summer. The occurrence of mink hair in some of the scats was ascribed to

\section{TABLE 1}

Levins' standardized niche breadth for mink on Navarino Island, estimated on the basis of scats collected in marine coastal, riparian, and lake habitats over the summer $(n=292)$, and for scats collected from marine habitats over different seasons of the year $(n=375)$

Amplitud de nicho trófico estandardizado de Levins para el visón en Isla Navarino, estimado a base de heces recolectadas en costa marina, riberas de ríos y lagos durante el verano $(\mathrm{n}=292)$, y de heces recolectadas en hábitats marinos durante diferentes estaciones del año $(\mathrm{n}=375)$

\begin{tabular}{|c|c|c|c|c|c|c|c|}
\hline \multirow[t]{2}{*}{ Index } & \multicolumn{3}{|c|}{ Habitat (summer) } & \multicolumn{4}{|c|}{ Season (marine coast) } \\
\hline & Marine & Rivers & Lakes & Spring & Summer & Autumn & Winter \\
\hline RFO & 0.78 & 0.45 & 0.47 & 0.64 & 0.78 & 0.52 & 0.35 \\
\hline $\mathrm{BIO}$ & 0.43 & 0.18 & 0.17 & 0.39 & 0.43 & 0.31 & 0.40 \\
\hline POD & 0.42 & 0.30 & 0.24 & 0.35 & 0.42 & 0.28 & 0.21 \\
\hline
\end{tabular}


grooming. In summary, the proportion of exotic mammals in terms of biomass was $49.9 \%$, a proportion that exceeds the value of $43.2 \%$ estimated for native mammals (the other $6.9 \%$ correspond to non identified mammal prey). The contribution of invertebrates to the mink's biomass intake $(2.9 \%)$ was negligible (Table

\section{TABLE 2}

Diet composition of American mink over the warm season (spring-summer) in marine coastal habitat on Navarino Island ( $\mathrm{n}=193$ scats, 20052007); RFO = relative frequency of occurrences, $\mathrm{BIO}=$ percentage of biomass, $\mathrm{POD}=$ percentage of occurrence of dominant item

Composición de la dieta del visón durante la temporada cálida (primavera-verano) en hábitat marino costero en Isla Navarino ( $\mathrm{n}=193$ heces, 2005-2007); RFO = frecuencia relativa de presencia, $\mathrm{BIO}=$ porcentaje biomasa, $\mathrm{POD}=$ porcentaje presencia del ítem dominante

\begin{tabular}{lccc}
\hline Prey & RFO & BIO & POD \\
\hline Abrothrix xanthorhinus & 8.9 & 10.1 & 14.8 \\
Mus musculus & 0.6 & 0.1 & 0.3 \\
Mustela vison & 2.4 & 1.3 & 3.8 \\
Oligoryzomys longicaudatus & 2.6 & 3.2 & 4.8 \\
Ondatra zibethicus & 8.7 & 13.9 & 15.2 \\
Unidentified mammals & 6.1 & 2.1 & 2.8 \\
Total mammals & 29.2 & 30.8 & 41.7 \\
& & & \\
Anseriformes & 3.9 & 5.1 & 6.9 \\
Ciconiformes & 1.3 & 1.7 & 2.4 \\
Coraciiformes & 0.4 & 0.3 & 0.7 \\
Gruiformes & 0.2 & 0.4 & 0.3 \\
Passeriformes & 10.2 & 11.3 & 14.8 \\
Pelecaniformes & 3.7 & 7.5 & 6.2 \\
Podicipediformes & 0.9 & 1.0 & 1.7 \\
Eggs & 3.9 & 6.6 & - \\
Unidentified birds & 6.3 & 6.2 & 6.6 \\
Total birds & 30.7 & 40.0 & 39.7 \\
Fish & & & \\
Arachnida, Acari & 15.5 & 26.3 & 14.8 \\
Coleoptera & 0.4 & - & - \\
Hemiptera, Heteroptera & 0.9 & - & - \\
Aegorhinus vitulus & 0.2 & - & - \\
Microplophorus magellanicus & 1.5 & 0.1 & 0.3 \\
Pycnosiphorus femoralis & 1.7 & 0.1 & 0.3 \\
Sinopla perpunctatus & 0.2 & - & - \\
Unidentified insects & 5.7 & - & 0.3 \\
Total insects & 10.7 & 0.3 & 1.0 \\
Crustaceans & 10.9 & 2.4 & 2.8 \\
Mollusks & 3.0 & 0.2 & - \\
\hline Food niche breadth & 0.68 & 0.42 & 0.36 \\
Total N items or biomass (g) & 541 & 2.566 .6 & 290 \\
\hline & & & \\
\hline
\end{tabular}

2). In spite of this however, mink seem to actively search for insects because all of the insect taxa identified, except for the coleoptera Microplophorus magellanicus (Blanchard, 1851), were flightless, and therewith easier to catch. Hence, insects were probably consumed directly by mink (although we cannot exclude consumption by other active hunters).

\section{Monthly food consumption of mink}

How hungry are mink? On average the daily food consumption of a mink is approximately $190 \mathrm{~g}$ (estimated from Dunstone 1993). Following our biomass fractions (BIO) of prey groups over the spring and summer we can estimate an extrapolated monthly (30 days) consumption, which does not take into account varying energy demands of the animal. Accordingly, a single mink would consume monthly on average: nine Passeriformes, four Anseriformes, six Pelecaniformes, 13 other birds (total birds: 32), 17 Abrothrix xanthorhinus, five Oligoryzomys longicaudatus, one muskrat, three other small rodents (total mammals: 26), and 13 fish. The small proportion of remaining prey groups (2.9 $\%$ BIO) was neglected in this estimation. Based on trapping data of mink on Navarino Island, mink relative densities ranged from 0.79-1.32 individuals $\mathrm{km}^{-1}$ along marine coastal habitat (Anderson et al. 2006a). Applying these densities to a $10 \mathrm{~km}$ stretch of coastline eight to thirteen mink living there could roughly consume about 248-415 small birds, 205-343 mammals, and 105-175 fish in one month during the warm season.

\section{DISCUSSION}

\section{Mammals as a reliable source, birds welcome when available}

Diet composition showed that mink relied principally on mammalian and avian prey with significant variations over habitats and seasons. In marine coastal habitat and in particular at lakes birds were the principal prey group. Over the warm season mink preyed on both vertebrate groups almost equally, but relied mainly on mammals over the cool season. These results suggest that mammals represent a 
stable base in the diet compensating for periods with lower bird availability .

Compared to other studies on mink diet worldwide, the proportion of birds in scats from marine coastal habitat on Navarino Island over the summer was exceptionally high. Further North in Argentinean Patagonia coastal mink predominantly prey on crustaceans and insects (Previtali et al. 1998). In Eurasia fish and crustaceans seem to be the most important prey for mink in marine habitat (Jedrzejewska et al. 2001, Delibes et al. 2004), although mammals can also play an important role (Dunstone \& Birks 1987). In riparian habitats, fish, mammals, and amphibians are reported as principal prey groups in the diet of introduced mink (Medina 1997, Ferreras \& Macdonald 1999, Jedrzejewska et al. 2001, Hammershøj et al. 2004). Noticeably, few studies report a high consumption of birds, which only occurred in productive waterbird breeding habitats and areas with large wildfowl populations in inland wetlands, especially during the warm season (Ward et al. 1986, Arnold \& Fritzell 1987, Bartoszewicz \& Zalewski 2003). Therefore, the opportunistic diet habits of the mink (Dunstone 1993) seem to reflect the abundance and diversity of prey available in each region.

The exceptionally high abundance of birds in the diet of mink at the southern end of the Americas might be explained by at least three factors: (i) in the insular austral environment amphibians and reptiles as possible prey groups are absent (ii) aquatic prey might play a minor role due to the climate conditions in combination with the greater level of energy expenditure used to catch it (Stephenson et al. 1988), and (iii) during the warm season, the density of birds returning from migration is high, the mobility of birds during incubation, brood rearing or moulting is reduced (Bartoszewicz \& Zalewski 2003), and many ground-nesting birds on Navarino supply vulnerable offspring.

\section{Impact on native prey populations}

In order to assess the direct ecological impact of mink on prey populations we must identify "sensitive species", i.e. species with low abundances, low hunting effort for mink, and high energy content (Dunstone 1993). Our identification of bird remains in mink scats is reliable to the level of orders. Consequently, we attempted to identify potentially sensitive species among the main orders we found in the diet of mink on Navarino Island. Passeriformes were the most abundant bird order in the diet, and furthermore affected as being caught as adults, i.e. as individuals contributing to the reproduction of the population. Although we don't know whether these passerines were ground or tree-nesting, we suggest that potentially sensitive species might be those that breed in open nests at low height, and present low abundances in the Cape Horn archipelago region. Based on avian censuses for Navarino Island (Anderson \& Rozzi 2000, Anderson et al. 2002, McGehee et al. 2004) these criteria target three species: the ground nesting Magellanic tapaculo (Scytalopus magellanicus Gmelin, 1789), the Patagonian tyrant (Colorhamphus parvirostris Darwin, 1839), and in particular the fire-eyed diucon (Xolmis pyrope Kittlitz, 1830) (Ippi personal communication). In inland wetlands bird species that are locally rare, such as the Fuegian snipe (Gallinago stricklandii Gray, 1845) (Couve \& Vidal 2003) might be threatened because in comparison to marine coastal habitats, inland wetlands on Navarino Island seem to harbor less potential prey for mink (lack of crustaceans, marine fish etc.).

With respect to large ground-nesting birds (e.g. Anseriformes, Pelecaniformes) our results confirm that mink predominantly caught their chicks. Among Anseriformes, two species endemic to the subantarctic archipelago region of southwestern South America (41-56 $\mathrm{S}$, including the Falklands) have small populations that might be particularly vulnerable to mink predation of their offsprings: the flightless steamer duck (Tachyeres pteneres Forster, 1844) and the kelp goose (Chloephaga hybrida Molina, 1782). Both species are strictly coastal, and they inhabit the area all year round (Couve $\&$ Vidal 2003). Their population densities along the coasts of the Beagle Channel $(0.74$, and 0.46 birds $\mathrm{km}^{-1}$ for $T$. pteneres and $C$. hybrida, respectively, estimated by Raya \& Schiavini 2002) are very low in the light of the numbers of birds consumed by mink in our numeric example (25-42 month $\left.{ }^{-1} \mathrm{~km}^{-1}\right)$.

Regarding native mammals, mink hunted native rodents in proportion to their availability. In the spring-summer diet we 
found three times more Abrothrix xanthorhinus than Oligoryzomys longicaudatus. This proportion resembles the relative abundances obtained for these two species through censuses with Sherman traps on the study sites on Navarino Island (Gañan et al. unpublished results). A. xanthorhinus was trapped six times more frequently than $O$. longicaudatus. For $A$. xanthorhinus Gañan et al. estimated mean relative densities of 8-39 individuals ha ${ }^{-1}$ (per 100 trap nights, depending on the habitat type: forest, pasture, reed, shrubland), and 0-6 individuals ha-1 for $O$. longicaudatus, respectively, during spring to autumn $(\mathrm{n}=$ 3,800 trap nights). Hence, based on our estimations for the consumption of native rodents from our biomass fractions in mink diet (17-29 month $\left.{ }^{-1} \mathrm{~km}^{-1}\right)$, it seems that Mustela vison does not represent a threat to these mammal species, although these rough estimates have to be treated with caution. The indirect impact of mink on changes in the prey offer for autochthonous bird predators requires further analysis.

\section{Exotic mammals as prey for mink}

Our results from marine coastal scats over the warm season show a considerable proportion of muskrat among mammal biomass consumed by mink on Navarino Island. Interestingly, this result coincides with studies from North America, where muskrats are the largest and probably most important mammalian prey for mink (Dunstone 1993). Over the winter months in particular young muskrat are vulnerable to mink predation (Errington 1954). Thus, populations of these two North American invasive mammals have reestablished their predator-prey interactions at the southern end of the continent. We lack systematic abundance data of the muskrat, but SAG's Control Program of Exotic Species in Magallanes (Soto \& Cabello 2007), reports that 250 muskrat were captured in Tierra del Fuego and the Cape Horn Region by a single trapper working in lake and riparian habitats over 2005/2006. We therefore assume that muskrat is a reliable and highly energetic source for mink. This result adds one more example of facilitatory interactions between an invasive species already present, the muskrat (arrival in the fifties, Jaksic et al. 2002), aiding a new species to establish
(Simberloff \& Von Holle 1999), although not in a mutual way.

As far as the other species of North American introduced rodents are concerned, we did not find any beaver remains in the diet of mink in marine habitats. This might be due to the fact that beavers are mostly associated with riparian habitats (Anderson et al. 2006b). Studies on mink scats $(n=235)$ collected in inland wetlands on Navarino Island have shown that only $2 \%$ contained beaver remains (Ibarra 2007). Again, these results for Navarino Island coincide with those found in North America (Dunstone 1993) and Europe (e.g. Brezezinski \& Zurowski 1992) where beavers are not reported as prey species. A probable explanation is that beavers are too large as prey for mink (their body weight ranges from 18-23 $\mathrm{kg}$, Aleksiuk 1968), and that young beavers are sufficiently guarded by their parents (Brezezinski \& Zurowski 1992). However, mink might profit from the coexistence with beavers, since their engineering activities provide denning facilities for the mink (Zurowski \& Kammler 1987).

\section{Concluding remarks}

Birds constituted an important prey group for the introduced mink on Navarino Island, especially in marine coastal habitat and lakes during the breeding season. Studies in other insular ecosystems have shown that the introduction of mink can lead to severe reductions of bird populations (Ferreras \& Macdonald 1999, Nordström \& Korpimäki 2003). We identified two Anseriformes (Tachyeres pteneres and Chloephaga hybrida) endemic to southern South America, which might be seriously threatened by the presence of mink on Navarino Island. For these reasons we advise governmental agencies (Iriarte et al. 2005) to start controlling mink populations immediately. In order to increase trapping success, control should take place mainly during periods of high activity of mink (spring and autumn, Moore et al. 2003), and with particular intensity at nesting habitats of sensitive bird species during their breeding periods (under the consideration of the trapper's influence).

For an integrated management of exotic species on Navarino Island and the Cape Horn Biosphere Reserve it is important to undertake 
further research on the direct and indirect interactions established here among the various introduced mammal species (Silva \& Saavedra 2008). The muskrat might protect native species from being preyed upon the opportunistic predator, but on the other hand it represents a reliable food source for the mink. Finally, we recommend that long-term monitoring of bird populations should accompany the mink management strategies that are currently being implemented in this remote region of the world. The critical need for conserving the avifauna and ecosystem integrity of the Cape Horn Biosphere Reserve is especially relevant for ecotourism, which currently represents the main option for achieving both economic and environmental sustainability at the southern end of the Americas (Rozzi et al. 2004).

\section{ACKNOWLEDGMENTS}

We thank José Llaipén for his great support in field work and laboratory analysis. Steven McGehee and Melisa Gañan assisted with the field work. We are grateful to Eduardo Faúndez who identified the insects. Kurt Jax and Jórge Gibbons provided helpful advice regarding scientific questions. We thank Carlos Soto and Alex Muñoz for hosting us in their laboratories. Jana Zschille provided us with experience and bibliographic citations. We express our gratitude to two anonymous reviewers whose comment's greatly improved the paper. The manuscript also benefited due to comments from Klaus Henle, Kurt Jax, Steven McGehee, Michael Gerisch, Simone Lampa, and Bianca Bauch. This work was co-sponsored by the German Academic Exchange Service (DAAD), by the Chilean Millennium Institute of Ecology and Biodiversity Contract (ICM, PO2-051-F), the Universidad de Magallanes, and the Omora Foundation.

\section{LITERATURE CITED}

AHOLA M, M NORDSTRÖM, PB BANKS, N LAANETU \& E KORPIMÄKI (2006) Alien mink predation induces prolonged declines in archipelago amphibians. Proceedings of the Royal Society B 273: 1261-1265.

ALEKSIUK M (1968) Scent mound communication, territoriality, and population regulation in the beaver. Journal of Mammalogy 49: 759-762.

ANDERSON CB \& R ROZZI (2000) Bird assemblages in the southernmost forests in the world: methodological variations for determining species composition. Anales del Instituto de la Patagonia 28: $89-100$

ANDERSON CB, R ROZZI, C ELPHICK \& S MCGEHEE (2002) El programa Omora de anillamiento de aves en los bosques subantárticos: la estandardización del tamaño de anillos apropiados para las aves de la región de Magallanes. Boletín Chileno de Ornitología 9: 2-11.

ANDERSON CB, R ROZZI, JC TORRES-MURA, SM MCGEHEE, MF SHERRIFFS, E SCHÜTTLER \& AD ROSEMOND (2006a) Exotic vertebrate fauna in the remote and pristine sub-Antarctic Cape Horn Archipelago, Chile. Biodiversity and Conservation 15: 3295-3313.

ANDERSON CB, CR GRIFFITH, AD ROSEMOND, R ROZZI \& O DOLLENZ (2006b) The effects of invasive North American beavers on riparian plant communities in Cape Horn, Chile. Do exotic beavers engineer differently in sub-Antarctic ecosystems? Biological Conservation 128: 467-474.

ARNOLD TW \& EK FRITZELL (1987) Food habits of prairie mink during the waterfowl breeding season. Canadian Journal of Zoology 68: 2322-2324.

BARTOSZEWICZ M \& A ZALEWSKI (2003) American mink, Mustela vison diet and predation on waterfowl in the Slonsk Reserve, western Poland. Folia Zoologica 52: 225-238

BONESI L \& S PALAZON (2007) The American mink in Europe: Status, impacts, and control. Biological Conservation 134: 470-483.

BREZEZINSKI M \& W ZUROWSKI (1992) Spring diet of the American mink Mustela vison in the Mazurian and Brodnica Lakelands, northern Poland. Acta Theriologica 37: 193-198.

BRZEZINSKI M \& M MARZEC (2003) Correction factors used for estimating prey biomass in the diet of American mink Mustela vison. Acta Theriologica 48: 247-254.

BUSCHING W-D (2005) Einführung in die Gefieder- und Rupfungskunde. AULA-Verlag GmbH, Wiebelsheim. 408 pp.

CHEHÉBAR C \& S MARTÍN (1989) Guía para el reconocimiento microscópico de los pelos de los mamíferos de la Patagonia. Doñana Acta Vertebrata 16: $247-291$.

CLODE D \& DW MACDONALD (2002) Invasive predators and the conservation of island birds: the case of American mink Mustela vison and terns Sterna spp. in the Western Isles, Scotland. Bird Study 49: 118-123.

COURCHAMP F, J-L CHAPUIS \& M PASCAL (2003) Mammal invaders on islands: impact, control and control impact. Biological Reviews 78: 347-383.

COUVE E \& C VIDAL (2003) Birds of the Beagle Channel and Cape Horn. Ediciones Fantástico Sur, Punta Arenas, Chile. 265 pp.

DAY MG (1966) Identification of hair and feather remains in the gut and faeces of stoats and weasels. Journal of Zoology 148: 201-217.

DELIBES M, M CLAVERO, J PRENDA, M DEL CARMEN-BLÁSQUEZ \& P FERRERAS (2004) Potential impact of an exotic mammal on rocky intertidal communities of northwestern Spain. Biological Invasions 6: 213-219.

DUNSTONE N \& JDS BIRKS (1987) The feeding ecology 
of mink (Mustela vison) in coastal habitat. Journal of Zoology 212: 69-83.

DUNSTONE N (1993) The mink. T \& AD Poyser Ltd., London, United Kingdom. 232 pp.

ELTON CS (1958) The ecology of invasions by animals and plants. Methuen and Company, London, United Kingdom. 181 pp.

ERRINGTON PL (1954) An analysis of mink predation upon muskrats in north-central United States. Iowa State Coll. Agricultural Experimental Station Research Bulletin 320: 798-924

EWART CJ (1921) The nestling feathers of the mallard, with observations on the composition, origin, and history of feathers. Proceedings of the Zoological Society of London 2: 609-642.

FERRERAS P \& DW MACDONALD (1999) The impact of American mink Mustela vison on water birds in the upper Thames. Journal of Applied Ecology 36: 701-708.

HAMMERSH $\varnothing \mathrm{J}$ M, EA THOMSEN \& AB MADSEN (2004) Diet of free-ranging American mink and European polecat in Denmark. Acta Theriologica 49: 337-347.

HURLBERT SH (1978) The measurement of niche overlap and some relatives. Ecology 59: 67-77.

IBARRA JT (2007) El visón en Upushwaia: Variaciones estacionales de la avifauna en ambientes de humedal y de su depredación por la especie exótica invasora Mustela vison (Schreber) en isla Navarino, Reserva de Biosfera Cabo de Hornos, Chile. Master thesis, Facultad de Agronomía e Ingeniería Forestal, Pontificia Universidad Católica de Chile, Santiago, Chile. $117 \mathrm{pp}$

IRIARTE JA, GA LOBOS \& FM JAKSIC (2005) Invasive vertebrate species in Chile and their control and monitoring by governmental agencies. Revista Chilena de Historia Natural 78: 143-154.

JAKSIC FM, JA IRIARTRE, JE JIMÉNEZ \& DR MARTÍNEZ (2002) Invaders without frontiers: cross-border invasions of exotic mammals. Biological Invasions 4: 157-173.

JEDRZEJEWSKA B \& W JEDRZEJEWSKI (1998) Predation in vertebrate communities. The Bialowieza Primeval Forest as a case study. Springer, Berlin, Germany. 450 pp.

JEDRZEJEWSKA B, VE SIDOROVICH, MM PIKULIK \& W JEDRZEJEWSKI (2001) Feeding habits of the otter and the American mink in Bialowieza Primeval Forest (Poland) compared to other Eurasian population. Ecography 24: 165-180.

JEFFERIES DJ (2003) The water vole and mink survey of Britain 1996-1998 with a history of the long term changes in the status of both species and their causes. The Vincent Wildlife Trust, Ledbury.

KREBS CJ (1999) Ecological methodology. Benjamin/ Cummings, Menlo Park, California, USA. 620 pp.

LEVINS R (1968) Evolution in changing environments: some theoretical explorations. Princeton University Press, Princeton, New Jersey, USA. 132 pp.

LIZZARALDE MS \& JM ESCOBAR (2000) Mamíferos exóticos en la Tierra del Fuego. Ciencia hoy (Chile) 10: $52-63$.

LOCKIE JD (1961) The food of the pine marten Martes martes in West Ross Shire, Scotland. Proceedings of the Zoological Society of London 136: 187-195.

LÓPEZ HL, ML GARCÍA \& NA SAN ROMÁN (1996) Lista comentada de la ictiofauna del canal Beagle, Tierra del Fuego, Argentina. Centro Austral de Investigaciones Científicas (CADIC), Ushuaia, Argentina. $84 \mathrm{pp}$
MACDONALD DW \& MD THOM (2001) Alien carnivores: unwelcome experiments in ecological theory. In: Gittleman JL, SM Funk, DW Macdonald \& RK Wayne (eds) Carnivore conservation: 93-122. Cambridge University Press, Cambridge, United Kingdom.

MACDONALD DW \& LA HARRINGTON (2003) The American mink: the triumph and tragedy of adaptation out of context. New Zealand Journal of Zoology 30: 421-441

MARAN T, H KRUUK, DW MACDONALD \& M POLMA (1998) Diet of two species of mink in Estonia: displacement of Mustela lutreola by $M$. vison. Journal of Zoology 245: 218-222.

MCGEHEE S, R ROZZI, S IPPI, CB ANDERSON, R VÁSQUEZ \& S WOODLAND (2004) Late-summer presence of the Patagonian tyrant, Colorhamphus parvirostris (Darwin) in Navarino Island, Cape Horn county. Anales del Instituto de la Patagonia (Chile) 32: 25-33

MEDINA G (1997) A comparison of the diet and distribution of southern river otter (Lutra provocax) and mink (Mustela vison) in southern Chile. Journal of Zoology London 242: 291-297.

MITTERMEIER RA, CG MITTERMEIER, TM BROOKS, JD PILGRIM, WR KONSTANT, GAB DA FONSECA \& C KORMOS (2003) Wilderness and biodiversity conservation. Proceedings of the National Academy of Sciences of the United States of America 18: 10309-10313.

MOORE NP, SS ROY \& A HELYAR (2003) Mink (Mustela vison) eradication to protect groundnesting birds in the Western Isles, Scotland, United Kingdom. New Zealand Journal of Zoology 30: 443-452.

MOORMAN MC (2007) The conservation implications of introduced trout and beaver on native fish in the Cape Horn Biosphere Reserve, Chile. Master thesis, North Carolina State University, Raleigh, North Carolina, USA. 57 pp.

NORDSTRÖM M \& E KORPIMÄKI (2003) Effects of island isolation and feral mink removal on bird communities on small islands in the Baltic Sea. Journal of Animal Ecology 73: 424-433.

NORDSTRÖM M, J LAINE, M AHOLA \& E KORPIMÄKI (2004) Reduced nest defence intensity and improved breeding success in terns as responses to removal of non-native American mink. Behavioral Ecology and Sociobiology 55: 454-460.

PAGNONI GO, JL GARRIDO \& MR MARÍN (1986) Impacto económico y ambiental del visón, Mustela vison (Schreber, 1877) en el norte de la Patagonia. Centro Nacional Patagónico (CENPAT)-Consejo Nacional de Investigaciones Científicas y Técnicas (CONICET), Dirección de Fauna Silvestre, Provincia de Chubut, Argentina. 20 pp.

PISANO E (1977) Fitogeografía de fuego-patagonia chilena. I. Comunidades vegetales entre las latitudes $52^{\circ}$ y $56^{\circ} \mathrm{S}$. Anales del Instituto de la Patagonia (Chile) 8: 121-250.

PREVITALI A, MH CASSINI, DW MACDONALD (1998) Habitat use and diet of the American mink (Mustela vison) in Argentinian Patagonia. Journal of Zoology London 246: 482-486.

R DEVELOPMENT CORE TEAM (2008) R: a language and environment for statistical computing. R Foundation for Statistical Computing, Vienna, Austria. ISBN 3-900051-07-0, URL http://www.Rproject.org/. Cited 14 Jun 2008.

RAU J \& DR MARTÍNEZ (2004) Identificación de los 
órdenes de aves chilenas a través de la microestructura de sus plumas. In: Muñoz A, Rau J \& J Valenzuela (eds) Aves rapaces de Chile: 229234. CEA Ediciones, Validiva, Chile.

RAYA-REY AR \& A SCHIAVINI (2002) Distribution and density of kelp geese and flightless steamer ducks along the Beagle Channel, Tierra del Fuego, Argentina. Waterbirds 25: 225-229.

REISE D (1973) Clave para la identificación de los cráneos de marsupiales y roedores chilenos. Gayana (Chile) 27: 1-20.

REYES CF (1992) Clave para la identificación de los órdenes de aves chilenas: microestructura de los nodos de las bárbulas. Thesis, Instituto Profesional de Osorno, Osorno, Chile. $81 \mathrm{pp}$.

ROZZI R \& M SHERRIFFS (2003) El visón (Mustela vison Schreber, Carnivora: Mustelidae), un nuevo mamífero exótico para la isla Navarino. Anales del Instituto de la Patagonia (Chile) 31: 97-104.

ROZZI R, F MASSARDO \& C ANDERSON (eds) (2004) The Cape Horn Biosphere Reserve: a proposal for conservation and tourism to achieve sustainable development at the southern end of the Americas. Bilingual English-Spanish Edition. Ediciones Universidad de Magallanes, Punta Arenas, Chile. $264 \mathrm{pp}$.

ROZZI R, F MASSARDO, A BERGHÖFER, CB ANDERSON, A MANSILLA, M MANSILLA, J PLANA, U BERGHÖFER, P ARAYA \& E BARROS (2006a) Cape Horn Biosphere Reserve: nomination document for the incorporation of the Cape Horn Archipelago territory into the Word Biosphere Reserve Network. MaB Program UNESCO. Ediciones de la Universidad de Magallanes, Punta Arenas, Chile

ROZZI R, F MASSARDO, CB ANDERSON, K HEIDINGER \& J SILANDER (2006b) Ten principles for biocultural conservation at the southern tip of the Americas: the approach of the Omora Enthnobotanical Park. Ecology and Society 11: 43 [online] www.ecologyandsociety.org/vol11/ iss $1 / \operatorname{art} 43 /$.

SALA OE, FS CHAPIN-III, JJ ARMESTO, E BERLOW, J BLOOMFIELD, R DIRZO, E HUBER-SANWALD,
LF HUENNEKE, RB JACKSON, A KINZIG, R LEEMANS, DM LODGE, HA MOONEY, M OESTERHELD, NL POFF, MT SYKES, BH WALKER, M WALKER \& DH WALL (2000) Global biodiversity scenarios for the year 2100 . Science 287: 1770-1774.

SANDOVAL RJ (1994) Estudio ecológico del visón asilvestrado (Mustela vison, Schreber) en la XI Región. Thesis, Universidad Austral de Chile, Valdivia, Chile. 74 pp.

SIDOROVICH VE, DW MACDONALD, MM PIKULIK \& H KRUUK (2001) Individual feeding specialization in the European mink, Mustela lutreola and the American mink, $M$. vison in north-eastern Belarus. Folia Zoologica 50: 27-42

SILVA CA \& B SAAVEDRA (2008) Knowing for controlling: ecological effects of invasive vertebrates in Tierra del Fuego. Revista Chilena de Historia Natural 81: 123-136.

SIMBERLOFF D \& B VON HOLLE (1999) Positive interactions of nonindigenous species: invasional meltdown? Biological Invasions 1: 21-32.

SOTO N \& J CABELLO (2007) Informe final: programa control de fauna dañina en la XIIa Región 20042007. SAG-FONDEMA, Servicio Agrícola y Ganadero, Magallanes y Antártica Chilena, Punta Arenas. $59 \mathrm{pp}+$ appendix.

STEPHENSON R, PJ BUTLER, N DUNSTONE \& AJ WOAKES (1988) Heart rate and gas exchange in freely diving American mink (Mustela vison). Journal of Experimental Biology 134: 435-442.

VITOUSEK PM, CM D'ANTONIO, LL LOOPE, M REJMÁNEK \& $R$ WESTBROOKS (1997) Introduced species: a significant component of human-caused global change. New Zealand Journal of Ecology 21: 1-16.

WARD DP, CM SMAL \& JS FAIRLEY (1986) The food of mink Mustela vison in the irish midlands. Proceedings of the Royal Irish Academy Section B 86: 169-182.

ZUROWSKI W \& J KAMMLER (1987) American mink (Mustela vison Schreber, 1777) in beaver's sites. Przeglad Zoologiczny 31: 513-521. 